\title{
Overview of Malaysian Modularity Manufacturing Practices
}

\author{
Noor Raihani Binti Zainol ${ }^{1}$, Abdullah Al-Mamun ${ }^{2 *}$, P. Yukthamarani Permarupan ${ }^{1}$ \\ ${ }^{1}$ Faculty of Entrepreneurship and Management, Universiti Malaysia Kelantan, Kota Bharu, Malaysia; ${ }^{2}$ Faculty of Entrepreneurship \\ and Management, Universiti Malaysia Kelantan, Kota Bharu, Malaysia. \\ Email: *abdullah.a@umk.edu.my
}

Received September $10^{\text {th }}, 2103$; revised October $10^{\text {th }}, 2013$; accepted October $15^{\text {th }}, 2013$

Copyright (C) 2013 Noor Raihani Binti Zainol et al. This is an open access article distributed under the Creative Commons Attribution License, which permits unrestricted use, distribution, and reproduction in any medium, provided the original work is properly cited.

\begin{abstract}
Modules and modularity have been popular concepts in operations research instead of products used in Malaysia. In the latest development, Modularity is very important in product design of manufacturing considerations for efficient assembly and complexity to make it better and fasten the process and products. The paper present is a study on overview of modularity products and manufacturing practices in Malaysia such as Traditional Malay House, fordable chair and maintaining services. The process of modularization makes the functional independence as the goal of good design. For the best marketing and end user, industry using modularization process or products leads to creation of product families and uniformity. To make the process of modularity successful, the industry has to ensure that modularity should maintain independence between components and processes in different modules and interchangeability between modules. This paper discusses the modules and modularity which are applied among the manufacturing in the Malaysia in the context of physical products and services.
\end{abstract}

Keywords: Modules; Modularity; Manufacturing; Interchangeability

\section{Introduction}

In the Malaysian market, most of the consumer products have methods of operation that are similar to function, such as a electric motor to rotate the blade of a blender, extractor and beater of a mixer but not surprisingly, initially they are designed distinctly different from the others products. Thus, modularity is considered as one of the best design concepts as it promotes faster and better designing process, functional independence and physical similarities, which makes the concept of modularity drive better platform development [1]. The researcher applied the modularity approach which makes it easy to design platform for multi-family product, consisting of flour mixer, electric blender and juice extractor, which can be shared among products [2].

Furthermore, the modularity approaches were used in many home appliances which are familiar with the consumer. The maintainability of a domestic product such as an electric coffee maker was applied to designing modularity which can identify its functional components and

\footnotetext{
${ }^{*}$ Corresponding author.
}

the interactions between the components [3]. The service mode of the product was determined so as to ascertain the level of service difficulty faced by the user. Guidelines in design for maintenance were applied during modifications to the existing design, focusing on three components in the main module of the product consisting of the cover of the base, the spraying unit and the cover of the strainer aperture [4]. The design has certainly enhanced the product's maintainability as well as reliability. In this way, the enhancement to product maintenance starts with a clear understanding of the interface among the product modules, which enables identification of functions, components and operation of the product [5]. Few authors discussed the relationship between design for modularity and maintenance in order to extend product life [1]. Modularization is also known as an engineering approach to simplifying component or product configuration as functional independence demands. This loose interaction characteristic makes the maintenance process easier, especially in term of maintenance time in an example of rear motorcycle brake system.

Moreover, development in the construction industry 
shows that modular system has turned out to be important in the process of industrialization. Thus, studies try to bring out a very important concept of modularity that exists in the Traditional Malay House [6]. Traditional Malay House is divided into several different components such as the basic structure, floor, and walls which include door and window panels and not forgetting roofs. Traditional Malay House basically can be divided into several modular, identified spaces and components. Spaces such as "rumah ibu”, "rumah dapur", and "serambi” can be labelled as modular spaces. While, components consisting of walls, door, windows, basic structural components and the roofs can be labeled as modular components. Traditional Malay House is a living testimony to the skills and knowledge on modular system of construction existing among the indigenous population and has the potentials to be developed and utilized in the near future [7]. Furthermore, without using the concept of modularity, a consistent dimensioning system in Traditional Malay House cannot be standardized [8].

In many centuries, the folding chair was considered one of the most important pieces of furniture in the house and a prized status symbol. In ancient civilizations, folding stools were used not merely for sitting but also for ceremonial use. The design of the foldable chair had been improved continuously by researcher and engineers to achieve the best design and mobility suited to the user requirements by applying the modular design [9].

The construction sector usually encounters problems in the field work. Problems such as rework, delay and low quality finishing or lower productivity are often caused by existing design flaws which are in the design phase [10]. An alternative solution to this problem is implementing constructability concept. Constructability concept talks about integrating construction resource, knowledge, experience and technology into the practice engineering and designing of a project [11]. From 1998, the Malaysian government through Construction Industry Development Board (CIDB) took some serious actions to reform the existing construction practice which currently employs conventional method towards industrialization concept. One of the main strategies taken by the government is to introduce a concept of design prefabrication, pre-assembly and modularization especially when it comes to public projects, at the mean time, it is also an initiative taken by the Malaysian construction industry to implement this system and the concept of constructability enhanced [12].

The introduction of modular concept into the construction industry not only provides dimensional basis for the coordination of dimensions and of those practitioners incorporating them, but it also acts as a tool towards the process of rationalization and industrialization of the whole building industry. Modular coordination in con- struction industry is not a new concept; it is well documented in the Malaysian Standard MS 10064: Part 1-10: 2001 [13]. Modular coordination is purely based on the utilization of modules in the form of basic module and multi-modules, therefore, it is a benchmark system to define the practice of coordinating spaces and zones for building parts and for the components which form them.

The usage of modular coordination concept in Industrialized Building System (IBS) can be applied to the design process, manufacture and assembly of components, building components and installations, and it affects the twin factors of position and dimension [14]. Therefore, whenever the question of size, position fit and minimum onsite modification arises, modular coordination concept is found to be relevant [15]. Thus, modular coordination can be applied to a wide range of contraction technologies, ranging from component building through partial prefabrication to rationalized traditional building methods.

\section{Modularity in Domestic Products}

One of the characteristics of a good design is consideration on the product's life cycle requirements [16]. Maintenance is one aspect of product engineering life cycle that refers to the level at which a design can be maintained or repaired efficiently and economically $[17,18]$. In many of the existing domestic appliances, design for ease of maintenance was not taken into consideration. Due to this, products were disposed off even though the defects are minor and repairable. According to FitzGerald, if the maintainability of products is considered from the early stage of design, servicing cost and down time can be reduced [17]. Furthermore, reduction in maintenance requirements can only be done by building maintainability into products or systems at the design stage [19]. While, Ullman stated that difficulty in servicing by the user can be due to design mistakes which are done on purpose [20]. In addition, components that can be replaced are limited to certain models only. Users are also negligent on maintenance that can be partly due to producers' refusal to share information openly with their customers. This has led to reduction in products' efficiency, wastage and increase in the quantity of waste disposal.

Moreover, modular building concept divides a system into two, which consist of physical and functional modules that can be arranged to facilitate design and servicing [5]. An important consideration when defining modularity is the choice on the level of servicing, which reflects ease of diagnosis and repair on a product. A product may be modular from the perspective of design but may be otherwise from the perspective of servicing operation. The design architecture of an electric coffee 
maker is reviewed and service modularity applied and the basis for design improvements to the electric coffee maker can improve the maintenance [4].

The components, functions and operation of the product will be identified in order to determine design modularity and maintainability in view of modifying its existing design for ease of maintenance. Thereby, to redesigning the product for ease maintenance, include of maintaining independence among components, components similarity and maintaining interchangeability [21]. The process on the use of electric coffee maker involved the activities, such as preparation, implementation and disposal. Firstly, the preparation level involves activities such as purchasing, product delivery, opening of the packaging, and storage after use. Secondly, the implementation stage involves appliance cleaning, inspection of the electrical resistor and mixing coffee. Finally, at the disposal stage, the appliance undergoes cleaning after use, storage and finally disposal at the end of its service life [22].

According to Dzuraidah et al., common failures of the electric coffee maker were identified together with the effects of failure to the components and their effect to the functioning of the product, as well as the diagnosis and servicing operation of the product [4]. For example, a user may find that his coffee gets cold very quickly. This failure could be due to the product's inability to maintain the right temperature for the coffee. The servicing mode for this failure is inspection to the heating unit that requires disassembly of the screw at the base and checking the connections of the wire and heating unit to the heating plate [3]. Therefore, the servicing and repair work involves inspection to the heating unit and electrical connection at the base of the electric coffee maker.

The product's service modularity and suggesting design improvements for ease of maintenance, including three components of the main module, such as the base cover and internal parts of the heating unit, spraying head in the distribution unit and the cover of the filtration unit [4]. In the existing design, the spraying tube is separated from the spraying head. This means that if the tube is cracked or broken, changing the tube will require the head to be detached from the tube. From the aspect of modularity, the tube is not independent and replacement of the tube may cause damage to other components. In order to maintain independence among components for maintainability, the spraying head and the tubing were combined so that the whole component can be replaced without affecting other components [3]. From the aspect of maintenance cost, the design will provide cost saving as it will not affect other components [23]. Furthermore, the development of combined components will be more cost effective in terms of manufacturing and assembly as compared to separate components. This modification will certainly improve the reliability of the product [3]. The new design will prevent blockage in the spraying unit. The spring controlled aperture at the filter swivel is in direct contact with the liquid that flows through the aperture, causing the spring to rust easily. Thus, to overcome this problem, the design of the spring controlled cover was modified to prevent fluid from flowing through the spring when the rubber cover is opened. This new design will certainly enhance the reliability of the spring [4].

Design modifications to the product, especially on the heating unit, the storage and distribution unit and the filtering unit was implemented without affecting the interaction and operations of the product in order to retain design modularity [4]. Several design improvements such as redesigning the cover of the base to improve accessibility, replacement of non standard fasteners and component independence, for enhancing product maintenance using the modularity approach. An early infusion of the guidelines on design for maintenance during the design architecture stage has enabled configuration determination, component inspection and selection of servicing modes to be identified in a more systematic and efficient manner [23].

According to Abdullah et al., a similar product platform means that a part of one product which can be shared and fit into another product among its variants to perform different functions [1]. Product simplification is achieved through modular architecture. However, modular architecture does not mean that the number of parts has been reduced; this is because addition of some parts can improve overall product performance [2]. For an example, a particular product without components such as screws and nuts may not require many tools in assembly. Modular products are special and it attracts customers as they are easy to use and can be upgraded [21].

According to Sudjianto et al., modularity can enhance the whole process of platform development from multibrand product perspective [24], and modularity index was used to identify which platforms that can be shared among different products from similar brand and family [1]. Therefore, the researcher argued that the multi-family products can be described as products which are different in the form of function and physical appearance, and can be used to enhance the design of a platform from a different multi-family product which generally has variations in product configurations [2].

Furthermore, Abdullah et al. considers three types of consumer products from different families, which consist of flour mixer, blender and juice extractor [2]. All the three products are share some kind of similarities in the terms of functionality, but the physical differences sets them apart. Based from reading, modularity approach included into the design of a multi-family product can 
improve the performance and in return attracts more customers. Otherwise, using modularity approach can reduce the cost of development where the modules can easily be identified and the similarities between the modules are identified in product function structure and can be used to design a product platform [21].

According to Abdullah et al., the problems of each product must be identified and understood at the beginning phase itself. In order to have a clear understanding of the product functionality, it should be broken down into smaller and simple parts and components, and then, every part and component's functionality is presented in a form of black box model, and later on, the function structures for each product can be developed using modularity approach [1]. After the process of identifying the platform by using modularity approach, all the potential features can be taken into consideration, for an example, remote control [2]. Another potential is identifying the ways to enhance the cleaning process of parts and components from wastage and dirt. Beyond that, waste storing or cleaning module is an extra potential feature in the product. As a modification, new part can be fitted in to the juice extractor's variant so that the waste can be extracted without disassembling all the other components which will cause the machine to function for some time, this can be very inconvenient to the users. This is because, a typically juice extractor consists of a blade, and a main housing and a top cover that need to be disassembled first before the waste can be removed [25].

The coupling or decoupling module is one of the potential enhancements that will increase the product performance. It ensures that the rubber gear and the drive couple in a blender can be efficiently attached and detached. Another module that has the potential to improve the overall product performance is the actuating module, where a remote control can be added into the bundle. The remote control gives users the freedom to use it even if they are not in the kitchen [2].

\section{Modularity in Enhance Product Maintainability}

Product design and assembly type will affect the maintainability efficiency, that make the companies are struggling to achieved not only the best design but also provide a maintenance-friendly features that could increase their product performance. Thus, proper and simpler maintenances can extend product life-cycle [26]. It is very crucial in maintenance time to repair is and depends mainly on the product or system configurations. Thereafter, by simplifying the product configuration, repair and maintenance can be accomplished in shorter time. Modularity is believed capable to makes maintenance simpler due to functional independence created in the product configuration [4].

Moreover, design for assembly have similar characteristic in nature to design for modularity, where they try to achieve the highest level of simplification and standardization in product design. In maintainability, disassembly and reassembly is the most critical factor, which includes time of least replacement of components. Maintainability can be measured based on time consume in completing the task or mean time to repair and maintenance activity time [26].

Cost of assembly or disassembly is critical only in selection of appropriate tools [27]. Meanwhile, Tsai et al., introduces modularity operations and considering reliability and maintenance cost as a measure [28]. There also have problems that should be considered in maintainability analysis, which are disassembly sequence, selection of tools, time required for disassembly and human factor issues such as accessibility and visibility. Maintainability also should consider optimal resources such as personnel and support equipment [29]. The maintainability depends on the component accessibility, location of the targeted components and the skill of the operator. The lesser workload requires in accessing the component, the better maintainability. Moreover the higher level of skill of the operator, the faster maintenance can be done and determining more efficiency of the product [26].

\section{Modularity Concept in Construction (Traditional Malay House)}

Traditional Malay House (TMH) in Malaysia is slowly becoming extinct. It is very rare a new Traditional Malay House being built throughout the country for normal living purposes other than for ceremonial or heritage exhibition purposes. Culture and tradition is an identity to a society that needs to be preserved for future generation, which is not untouchable. TMH has got many good aspects, technically, socially and environmentally that need to be explored and adopted in the modern contemporary built environment [6].

Furthermore, technical aspects of Traditional Malay House were quiet abandoned and rarely studied. The researcher focused on the elements of construction techniques of the Traditional Malay House for future utilization of the concept of modularity that seems to be instilled in Traditional Malay House. Prebuilt nature of Traditional Malay House requires the right ingredient and a proper management practice to grant Traditional Malay House a chance to see the light of modernization and industrialization $[6,30]$.

Readers Digest Word Power Dictionary reads that, a module is an unit that builds part of something bigger, could be a single part or multiple units that can be 
brought together to make a machine, a piece of furniture, or even a building. According to Hamid et al., a module is a basic convenient unit used as a coefficient in dimensional coordination [15]. The second definition is better suited to the intention and purpose of Traditional Malay House considering the dimensioning system. The principle of repetition remains as the core which rhythms in architecture. The concept of rhythm has been used to symbolize to the repetition of uniformed dimensions, such as window sections, heights, spans or other important dimensions in the front or plan of a building [30]. Building can be divided into three aspects such as physical, functional and spatial. Physical elements look at the structure of the building, the exterior, materials used for construction and colors of the building. Spatial are more related to space and the position of the building, it also includes size and shape. Lastly, functional elements looks into functionality of the building, where the spaces and environment suits to the functions that are about to be carried out in the building [31].

Furthermore, physical elements of a building can be divided into three elements of components; sections, units and compound units. Units is a single standalone component but can also form a part of something that is larger, such as brick, tile, block, window pane, lintel, door leaf, panel, pipe and pipe fitting. Then, compound unit is a combination of two or more individual things put together, such as a door with frame, refrigerator, lattice girder, cupboard, sink unit, window, and roof truss. This means that, a unit and a compound unit can be count as a module. Therefore any part of a building or even a whole building build from such units can be labeled as "modular building" [6].

Moreover, a Traditional Malay House (TMH) can be labelled as a vernacular architecture as it is the architecture of the local people, and it here in Peninsula Malaysia even before the colonialism period [7]. All Traditional Malay House were basically built out of timber as it is the only building material existed and was abundantly found material, TMH are build elevated on stilt and consists of three main spaces known as "rumah ibu", "rumah tengah" and "rumah dapur". These traditional houses are covered with a long roof with some variations based on regions of origin. It continued to evolve over generations according to their way of living, adapting to the changes in needs, and surviving the changes in culture and environment [30]. Traditional Malay House creates a sense of responsibility while connecting to the society and build environment and is self-contained. The Traditional Malay House is the outcome of high creativity and craftsmanship among the Malays [32]. The traditional houses in Malaysia symbolize its history and cultural heritage. The traditional Malay houses are always built based on a clear pattern and order. A basic Traditional Malay House includes a verandah known as "selasar" or "serambi", a main room known as "rumah ibu" which consist a sleeping area and the kitchen known as "dapor" at the back of each house [33].

The architecture of traditional Malay house is very special that it created a near-perfect solutions to the changes of climate, multi-functional use of space to fit various functions, flexibility in design which allows modifications and a sophisticated prebuilt system which can extend the house space with the growing needs of the family [7]. The basic unit of Traditional Malay House is known as "rumah bujang" which holds one space module with six columns or even known as "rumah tiang enam" with eight columns.

The modular pattern important in Traditional Malay House poses and relate to the current development in modular building concept in the current construction industry which associated itself with preexisting modular design, prefabrication and industrialization [34]. Modular Coordination design rules were used as a tool for measuring dimension and analysis. Modular Coordination is itself considered as a tool for dimensional coordination and standardization. Modular Coordination is a method where sizing dimensions of building components and of building on the basis of a basic module happens. The international basic module is $\mathrm{M}$, where $\mathrm{M}=100 \mathrm{~mm}$ [15].

Based from the reading the articles, it was founded that the modular in Traditional Malay House can divided into modular component, such as physical element and spaces including the spatial and functional. The utilization of modularity and repetitiveness concept in Traditional Malay House has a lot to offer to the development of modern building construction focusing on housing in Malaysia. Prefabrication brings Traditional Malay House to modernization and industrialization. Obviously, prefabrication is a method which enables wider gains out from series of uniform dimensions or modular. The whole spectrum of repetition and uniform sizes opens a new path for industrialization of production, which can be useful not only to Traditional Malay House but also to the construction industry as a whole [6].

\section{Modularity in Construction Based on Civ- il Engineering}

The concept of constructability was first coined in the late 1970s, the aim of constructability is to integrate engineering, construction, operation knowledge and experience in order to increase cost efficiency and quality in achieving project objectives in the construction industry [35]. Process implementation, integration and assessment of constructability concept during design phase has been studied by researchers in the Malaysian context, as noted 
by $[10,14,36]$, but these concepts have not been tested in Malaysia [36]. There is a total of 23 constructability concepts which were formulated to fit into the engineered construction phases. The engineered construction phase includes everything from the process of planning and design until the end of a specific project [36].

The basic idea of offsite construction is to move some effort away from the construction site itself to a more controlled environment. Offsite means the whole process of manufacturing and pre-assembly of components, elements or modules before installing them into their final location. In addition, offsite construction refers to part of the construction process that is done out away from the actual building site, such as in factory or in a specially created temporary production facilities close to the construction site [11]. According to Hamid et al., the offsite construction concept benefits the construction sector from the aspects of improvement in quality, cost and time certainty and increases customer and environmental satisfaction [15].

Furthermore, offsite construction concept improves constructability by providing designers with new perspective and view on the concept of repetition, preassembly and standardization. This is why the integration of modularization and preassembly for project elements should be given importance and studied carefully [11]. Modularization and preassembly design process should be utilized to facilitate fabrication, transportation and installation. In addition, repetition and standardization is deemed as dull and unattractive way of doing things, but rebranding effort of offsite construction concept recently gives a different view on the concept of sensible design where the concept of optimization can go in line with trend and awareness on sustainability issues [10]. The usage of modular coordination concept to design offsite components will increase the overall constructability in construction projects. Modular coordination is based on the concept of coordination of dimension and spaces where both building and components are positioned into a single unit or module known as $1 \mathrm{M}$ which is equivalent to $100 \mathrm{~mm}$ [15]. Based on recent research, it was founded that modular coordination concept can be used to design conventional system, but it is more suitable for offsite and production of components where repetitiveness exists.

In Malaysia, Industrialized Building System (IBS) is being widely used by the state and industrialist to represent offsite construction concept. IBS is a construction technique where construction parts are manufactured in a controlled environment which can be on or off site. The build components are later transported, positioned and assembled into a complete structure where additional site works are kept minimal [13]. IBS also blankets modular coordination and Open Building System (OBS) concept
[13]. IBS was introduced in Malaysia in the 60's, which started with the use of pre-cast method to build concrete beam-column and the use of panelized system [13].

The project which was carried out in Rifle Range, Penang and Jalan Pekeliling, Kuala Lumpur had employed French Estoit and Danish System respectively. But both the systems were not used as it was found not suitable for local cultural habits. The abundance of foreign workers in the 1990's, has reignited the interest on IBS. Housing Research Centre (HRC), based at Universiti Putra Malaysia pioneered in the area of research and promotion of IBS. HRC took the initiative to organize a series of national and international colloquiums and seminars on IBS.

In 2001, HRC's research on "Interlocking load bearing hollow-block building" named as "Putra Block" has won the prestigious "Geneva Gold Medal" award for innovation. On the same year HRC were also engaged with the Ministry of Housing and Local Government to conduct a research on the National Affordable Housing program. In 1999, IBS Strategic Plan 1999 were published, it was the outcome from the initiatives taken by Industry Development Board (CIDB) which formed IBS Steering Committee in order to create and incorporate all issues pertaining IBS into a single framework. In an effort to guide all the practitioners and decision makers in embracing IBS, the government through CIDB published "parliament endorsed' roadmap. It is known as the Industrialized Building Systems (IBS) Roadmap 20032010, the master plan is based on the 5-M Strategy (Materials-Components-Machines, Manpower, Monetary, Management-Processes-Methods and Marketing). The main aim of the roadmap is to introduce open building concept and industrialized construction industry by the year 2010 [37]. The roadmap initiative implementation phase is currently lead by two working groups; IBS Technical Committee and IBS Steering Committee. CIDB's IBS Center is holding the role of secretariat to monitor all the related activities. Even though IBS is around for over 40 years, the pace of implementation and usage is still low. But things have been changing drastically the last couple of years. According to CIDB, foreign experts from Japan, Australia, United States and Netherlands have teamed up with many Malaysian private companies to provide pre-cast solutions for their projects [37]. They have a number of IBS key projects such as:

1) 17 storey flats project along Jalan Pekeliling at the hearts of Kuala Lumpur by Gammon/ Larsen Nielsen using a Danish System of which utilize large panel of pre-fabricated system [37]

2) Hochtief/ Chee Seng using the French Estoit System, completed a housing project with 6 blocks of 17 storey flats and another 3 blocks of 18 storey flats at Jalan Rifle Range, Penang. 
3) British Research Establishment (BRE) in 1978 designed an IBS pre-cast system and component which was used to construct low cost housing in Taman Tun Sardon Housing project in Penang.

4) Perbadanan Kemajuan Negeri Selangor (PKNS) engaged in low cost houses and high cost bungalows project in Selangor. Praton Haus International based in Germany provided their pre-cast concrete technology for this project which was under the state government.

5) Dayabumi complex with 36 storey which was the first ever project used steel structure (part of IBS) as a method of construction in 1984, this project was carried out by Takenaka Corporation of Japan.

6) Light Rapid Transit (LRT), Kuala Lumpur International Airport (KLIA), Bukit Jalil National Sport Complex, Kuala Lumpur City Centre (KLCC) and School Teacher's Quarters utilized the hybrid construction method.

The following is the key events of IBS promotion and initiatives taken by the government in Malaysia by [13]:

1) The government plans to build 100,000 units of affordable houses through the implementation of IBS concept. On top of that, all future projects by the government should incorporate $50 \%$ of IBS concept where CIDB monitors through their IBS score manual.

2) The Construction Industry Master Plan 2006-2015 incorporates IBS construction method as means to change the future path of the Malaysian construction industry. It has been highlighted under the Strategic Thrust 5 of CIMP: Innovate through R \& D to adopt a new construction method.

3) From 2007, new incentives have been introduced for IBS adopter which includes the exemption of levy ( $0.125 \%$ from the total cost of the project) on contractors who use IBS concept in $50 \%$ of the process in building components since 1st January 2007 [15]

4) Since 2007, IBS Centre has been playing the role of consultant from their office located at Cheras. The centre includes IBS style show-house and holds a Research and Development facility. The R \& D department is known as Construction Research Institute of Malaysia and it is initiated to manage IBS research department.

5) The Ministry of Finance emphasizes on the full utilization of IBS concept for all the government's projects in Malaysia through their circular dated on October 2008. Through the circular, Malaysian Government increased the percentage of IBS usage in projects from $50 \%$ to $70 \%$. The government shows its seriousness in implementing IBS when more than 320 projects worth RM 9.43 billion where carried out by using the IBS concept as in February 2009.
IBS or simply known as offsite construction concept adoption can be a starting point to improve constructability in regards to the process of standardization, preassembly and repetitiveness [11]. On top of that, the government helps through incentives, research aid and promotion to create greater utilization of IBS, which may solve the issues surrounding constructability's implementation which indirectly could become a game changer for the process of enhancement of constructability. Meanwhile, the Malaysian government has been busy in implementing IBS concept in its projects, which looks as a good step in order to improve the level of constructability in the construction industry [37]

\section{Conclusion}

This study has successfully demonstrated the relationship between manufacturing and modularity product or process. In Malaysia, modularity is important in manufacturing especially in construction such as Industrialized Building System (IBS) and Traditional Malay House (TMH). The process of modularity in construction will enhance the scale of constructability in the construction industry. Besides that, modularity could be an effective approach to improving construction project in Malaysia in the sense of design for standardization, pre-assembly and repetitiveness. Modularization is due to functional independence in the product configuration in maintaining services for domestic products such as coffee maker, blender, juice extractor, and flour mixer which will affect the performance of the products. Otherwise, improvement of the products performance by using modular approach can attract the customer to use as home appliance products and also reduce the cost development. The architecture of products development such as fordable chair is used to test conformity and quality in modularity process. The benefits of modularity for manufacturing practices increase the flexibility of modularity and adaptability into design to adjust and adapt to change. Modularity makes the increase in product variety and ease of product update.

\section{REFERENCES}

[1] A. B. Abdullah and Z. M. Ripin, "Modularization to Support Product Platform for Redesign,” Modern Applied Science, Vol. 2, No. 2, 2008, pp. 19-28.

[2] A. B. Abdullah, A. K. Kamarudin and Z. M. Ripin, "Design of Multi-Family Product Platform by Using Modularity Approach,” Jurnal Teknologi, Vol. 42, No. A, 2005. pp. 75-90.

[3] J. K. Gershenson and G. J. Prasad, "Product Modularity and Its Effect on Service and Maintenance,” Proceedings of the 1997 Servicing and Reliability Conference, Knoxville, 20-22 May 1997.

http://www.me.mtu.edu/ jkgershe/lel/research/MARCON 
\%2797.pdf

[4] A. W. Dzuraidah, K. E. Ching, T. E. Boay, R. Ramli and A. Hussain, "Product Redesign for Ease of Maintenance: A Case Study," International Journal of Mechanical and Materials Engineering, Vol. 3, No. 2, 2008, pp. 153-159.

[5] B. Mostia, “Design for Maintainability,” 2004. http://www.controldesign.com/articles/2002/244/

[6] I. Zulkifli and S. A. Abdullah, "Modularity Concept in Traditional Malay House (TMH) in Malaysia,” 2006. http://www.epublication.fab.utm.my/202/1/ICCI2006S5P P24.pdf

[7] M. R. Tajuddin and S. Rajeh, "Housing the Architectural Heritage of the Malay World: The Traditional Houses,” Universiti Teknologi Malaysia, Johor Bahru, 2005.

[8] S. I. Ariffin, "Order in Traditional Malay House form," Oxford Brookes University, Oxford, 2001.

[9] F. I. Nizam, "The Development of Modular Product Design: Foldable Chair,” 2007.

http://library.utem.edu.my/index2.php?option=com_docm an\&task=doc_view\&gid=3400\&Itemid=342

[10] W. K. Siong, "Integrating Construction into the Design Process,” Ph.D. Thesis, University of Technology Malaysia, Johor Bahru, 2006.

[11] M. N. Nawi, K. A. M. Kamar, A. Lee, Z. Hamid, M. R Abdullah, A. T. Haron and M. Ariff, "Enhancement of Constructability Concept: Experience of Malaysian Offsite Construction Industry," Proceedings of CIB International Conference, Rotterdam, 5-9 October 2009.

[12] N. A. F. Malik, "Supply Chain Management in IBS Industry," Malaysian International IBS Exhibition (MIIE)," Construction Industry Development Board (CIDB), Malaysia, 2006.

[13] Construction Industry Development Board (CIDB), "Industry Info,” 2012.

https://www.cidb.gov.my/cidbweb/index.php?option=co m_content\&view=featured\&Itemid=182\&lang=en

[14] M. Z. Rosli, “Constructability Assessment of Project at Design Phase. Faculty of Civil Engineering,” Ph.D. Thesis, Universiti Teknologi Malaysia, Johor Bahru, 2004.

[15] Z. Hamid, K. A. M. Kamar, M. Zain, K Ghani and A. H. A. Rahim, "Industrialized Building System (IBS) in Malaysia: The Current State and R \& D Initiatives,” Malaysia Construction Research Journal, Vol. 2, No. 1, 2008, pp. 1-13.

[16] G. E. Dieter, "Engineering Design: A Materials and Processing Approach,” McGraw Hill, New York, 2000.

[17] A. FitzGerald, "Design for Maintainability: Reliability Analysis Centre,” Defense Technology Information Centre, New York, 2001. http://www.theriac.org/pdfs/startsheets/start2001_4.pdf

[18] T. C. Kuo, S. H. Huang and H. C. Zhang, "Design for Manufacturing and Design for X-Concepts, Applications and Perspective," Journal of Computers and Industrial Engineering, Vol. 41, No. 3, 2001, pp. 241-260. http://dx.doi.org/10.1016/S0360-8352(01)00045-6

[19] A. Desai and A. Mital, "Design for Maintenance: Basic Concepts and Review of Literature,” International Jour- nal Product Development, Vol. 3, No. 1, 2006, pp. 77121.

[20] D. G. Ullman, “The Mechanical Design Process,” McGraw-Hill, New York, 2003.

[21] C. C. Huang, "Overview of Modular Product Development,” Project National Sciences Council, Vol. 24, No. 3, 2000, pp. 149-165.

[22] K. N. Otto and K. L. Wood, "Product Design: Techniques in Reverse Engineering and New Product Development," Prentice Hall, Upper Saddle River, 2001.

[23] C. C. Huang and A. Kusiak, "Modularity in Design of Products," IEEE Transaction on Systems, Man and Cybernetics, Vol. 28, No. 1, 1998, pp. 66-77. http://dx.doi.org/10.1109/3468.650323

[24] A. Sudjianto and K. Otto, "Modularization to Support Multiple Brand Platforms," Proceedings of DETC: ASME Design Engineering Technical Conferences, Pittsburgh, 9-12 September 2001.

[25] R. B. Stone, K. L. Wood and R. H. Crawford, “A Heuristics Method for Identifying Modules for Products Architectures,” Design Studies, Vol. 21, No. 1, 2000, pp. 5-31. http://dx.doi.org/10.1016/S0142-694X(99)00003-4

[26] A. B. Abdullah, M. S. Yusoff and Z. M. Ripin, "Integration of Design for Modularity and Design for Assembly to Enhance Product Maintainability,” International Conference on Manufacturing and Material Processing, University Malaya, Kuala Lumpur, 14-16 March 2006, pp. 263-267.

http://eprints.usm.my/1480/1/Integration_Of_Design_For _Modularity_And_Design_For_Assembly_To_Enhance_ Product_Maintainability.pdf

[27] R. Vujesovic, R. Raskar, N. V. Yeturkuri, M. C. Jothishankar and S. H. Juang, "Simulation, Animation and Analysis of Design Disassembly for Maintainability Analysis," International Journal Production Research, Vol. 33, No. 1, 1995, pp. 2999-3022.

[28] Y. T. Tsai, K. S. Wang and S. P. Lo, “A Study of Modularity Operation of Systems Based on Maintenance Consideration,” Journal Engineering Design, Vol. 14, No. 1, 2003, pp. 41-56.

http://dx.doi.org/10.1080/0954482031000078108

[29] M. F. Wani and O. P. Gandhi, "Development of Maintainability Index for Mechanical Systems,” Reliability Engineering and System Safety, Vol. 65, No. 3, 1999, pp. 259-270. http://dx.doi.org/10.1016/S0951-8320(99)00004-6

[30] L. J. Yuan, “The Malay House: Rediscovering Malaysia’s Indigenous Shelter System,” Institut Masyarakat, Kuala Lumpur, 1987.

[31] W. B. W. Abidin, "The Malay House: Rationale and Change,” MIT, Cambridge, 1981.

[32] A. H. N. W. H. Teh, "Rumah Melayu Tradisi," Penerbit Fajar Bakti Sdn. Bhd, Kuala Lumpur, 1994.

[33] R. B. Shah, “The Terengganu Timber Malay House,” Badan Warisan Malaysia, Kuala Lumpur, 1988.

[34] CIDB News, “Industry Info,” 2002. https://www.cidb.gov.my/cidbweb/index.php?option=co 
m_content\&view=featured\&Itemid=182\&lang=en

[35] K. A. M. Kamar, M. Alshawi and Z. A. Hamid, "Industrialised Building System: The Critical Success Factors in BuHu," 9th International Postgraduate Research Conference (IPGRC), Salford, 29-30 January 2009.

[36] M. A. Nima, "Constructability Factors in the Malaysian Construction Industry,” Ph.D. Thesis, University Putra Ma- laysia, Kuala Lumpur, 2001.

[37] Construction Industry Development Board (CIDB), "Industry Info," 2003.

https://www.cidb.gov.my/cidbweb/index.php?option=co m_content\&view=featured\&Itemid=182\&lang=en 